\title{
LOST DECADES: LESSONS FROM POST-INDEPENDENCE LATIN AMERICA FOR TODAY'S AFRICA
}

\author{
Robert H. Bates \\ John H. Coatsworth \\ Jeffrey G. Williamson \\ Working Paper 12610 \\ http://www.nber.org/papers/w12610
}

NATIONAL BUREAU OF ECONOMIC RESEARCH

1050 Massachusetts Avenue

Cambridge, MA 02138

October 2006

The views expressed herein are those of the author(s) and do not necessarily reflect the views of the National Bureau of Economic Research.

(C) 2006 by Robert H. Bates, John H. Coatsworth, and Jeffrey G. Williamson. All rights reserved. Short sections of text, not to exceed two paragraphs, may be quoted without explicit permission provided that full credit, including $\odot$ notice, is given to the source. 
Lost Decades: Lessons from Post-Independence Latin America for Today's Africa

Robert H. Bates, John H. Coatsworth, and Jeffrey G. Williamson

NBER Working Paper No. 12610

October 2006

JEL No. N0,O10,O54,O55

\section{ABSTRACT}

Africa and Latin America secured their independence from European colonial rule a century and half apart: most of Latin America after 1820 and most of Africa after 1960. Despite the distance in time and space, they share important similarities. In each case independence was followed by political instability, violent conflict and economic stagnation lasting for about a half-century (lost decades). The parallels suggest that Africa might be exiting from a period of post-imperial collapse and entering a period of relative political stability and economic growth, as did Latin America a century and a half earlier.

Robert H. Bates

Harvard University

1737 Cambridge Street, Room N213

Cambridge, MA 02138

rbates@latte.harvard.edu

John H. Coatsworth

Harvard University

David Rockefeller Center for Latin American Study

1730 Cambridge Street, South Building

Cambridge, MA 02138

coatswor@fas.harvard.edu
Jeffrey G. Williamson

Department of Economics

216 Littauer Center

Harvard University

Cambridge, MA 02138

and NBER

jwilliam@fas.harvard.edu 


\section{African Lessons from Latin American History?}

Africa and Latin America secured their independence from European colonial rule a century and half apart: most of Latin America after $1820^{1}$ and most of Africa after 1960. Despite the distance in time and space, independence was followed in each case by political instability, violent conflict and economic stagnation (lost decades) lasting about a half-century. The parallels between post-independence Latin America and Africa invite comparison. We argue here that the failure to achieve stability and growth resulted from similarities in the conditions that produced those unfavorable outcomes. We also argue that the post-imperial experiences of Latin American history suggest that Africa might now be entering a period of relative political stability and economic growth. In exploring the comparison, we proceed sequentially, first addressing the epoch of imperial rule and collapse, and then the post-imperial 'lost decades.' Following the comparison, we discuss the subsequent revival in Latin America, its implications for modern Africa, and offer reasons for believing that the latter may be recovering from its post-imperial decline and entering an era of political stability and economic growth.

\section{Imperial Rule}

\section{Economic Integration, Imperial Deterrent and Stability}

Imperial rule brought entire regions around the globe into direct contact with the tensions and rivalries between European states. Most colonies, however, did not become directly involved in military conflicts. In Latin America, the Dutch invaded Brazil’s

\footnotetext{
${ }^{1}$ Cuba and Puerto Rico are exceptions.
} 
sugar-rich northeast (1630-54); Spain lost most of its Caribbean possessions in the seventeenth century and fought to defend the rest for most of the eighteenth; Spain and Portuguese Brazil skirmished over territory that is now Uruguay. But for the most part, the mainland colonies did not become arenas of conflict because the competing powers had little interest in acquiring them. The imperial occupation of Africa also occurred with a relatively high level of courteous harmony (Hopkins 1973; Pakenham 1991; Abernethy 2000), despite the belligerent nationalism that sparked the partition of the continent among the European powers. True, tensions rose in North Africa up to the Fashoda incident, ${ }^{2}$ but only during World War I did imperial armies clash on the continent. Diplomacy rather than warfare generally marked their relationships and the result was an absence of conflict.

Imperialism also brought a measure of economic integration. It fostered trade, if only because groups of colonies shared a single master. Trade and factor mobility were augmented within each of the imperial domains of Latin America. French-speaking territories in Africa formed a currency zone and sterling provided a common monetary standard for Britain’s African colonies. Central Africa maintained a free trade zone; Southern Africa maintained a common tariff; Britain promoted a common market for Uganda, Kenya and Tanzania in east Africa; and it also promoted the economic integration of Northern Rhodesia, Southern Rhodesia and Nyasaland in Central Africa.

\footnotetext{
2 The Fashoda Incident in Egyptian Sudan on September 8, 1898 was caused by territorial disputes between France and Great Britain. Both countries wanted to link together their colonies with a system of railroads. This led to the confrontation at Fashoda, where the French east-west axis met the British north-south axis.
} 
The imperial powers also successfully contained or repressed internal challenges to colonial rule. In Latin America, potential threats to colonial rule came from ambitious European settlers, enslaved Africans and their descendants, and burdened indigenous peasants. Colonial governments produced few public goods, spent nothing on education and next to nothing on infrastructure apart from fortresses and customs houses. Many functions of the modern state were left to associations formed by the settlers themselves: the church, the militia, the merchant guilds (consulados), and other private 'corporate' bodies. These settlers demanded more power, more privileges and lower taxes, and colonial courts and bureaucracies often served them better than the Crown. Spain and Portugal had virtually no police or professional military in their American colonies, but managed to deter (and occasionally suppress) settler-led revolts by maintaining their capacity to mobilize their vast imperial resources. This deterrent helped keep settler elites in line, as did the elites' need for imperial protection from the slaves and indigenous peasants that surrounded them. Large-scale revolts by Indian and slave populations were rare in Latin America, although low-intensity resistance was endemic (Coatsworth 1988).

Imperialism was also accompanied by an influx of European settlers into eastern and southern Africa in the early $20^{\text {th }}$ century and from Portugal into south central Africa in the 1950s. The settlers in Africa adopted repressive labor strategies, forcefully seized land, and drove the indigenous population into crowded reserves. By contrast, in Latin America the Crown had largely abandoned forced indigenous labor by the early 1600s (except in Peruvian mines) and made an effort to protect indigenous property rights. In both cases, natives were forced into formal labor markets to earn cash with which to pay taxes (Palmer and Parsons 1977). 


\section{Demographic Disaster and Indigenous Accommodation}

Perhaps the biggest difference between Latin American and African imperialism was its impact on demography. A century after Columbus’s first voyage, European disease had caused immense demographic damage in Latin America as the indigenous population shrank from perhaps 50 million in 1492 to as few as three to four million by the early seventeenth century (Livi-Bacci 2006). The Atlantic slave trade tried to substitute Africans for decimated indigenous Latin Americans but the addition of African slaves was far smaller than the subtraction of indigenous Latin Americans caused by European disease. Moreover, the Africans were not transported to the once densely populated highlands where the population losses were greatest, but mainly to the sugarrich tropics. The demographic collapse destroyed inherited power structures, facilitated religious and cultural assimilation, and helped raise the per capita income of the indigenous population which survived and resettled on the best lands. ${ }^{3}$ When the indigenous population finally began to grow again in the mid-late seventeenth century, more than half had already succumbed to European domination. The rest lived on the colonial fringe (e.g. the Mexican north, the southern cone, and the vast Amazonian interior).

While there is evidence of African epidemics occurring in the wake of imperial incursion in Africa (Kjekshus 1977), the death rate among the local populations never approached that which accompanied the massive collapse of indigenous Latin American populations. The forced emigration of more than nine million slaves to the Americas certainly had a positive impact on labor supplies, but it was relatively small and spread

\footnotetext{
${ }^{3}$ Note the demographic parallel with Alwyn Young's argument that today's HIV-AIDS raises the incomes of those Africans who survive the disease (Young 2005).
} 
out over four centuries. In contrast, local African political structures remained intact thus sometimes requiring the use of European military force to subjugate them. In other instances, as in Uganda and Northern Nigeria, occupation was achieved by aligning with local kingdoms or by pitting local groups against each other, i.e. by adopting policies of divide and conquer (or at least rule).

\section{Imperial Collapse}

It is important to stress that the decline of imperialism in both Latin America and Africa was not driven by some endogenous response to local forces but rather by exogenous events in Europe. In the former case, it was the Napoleonic wars that eroded Iberian imperial power, while in the latter it was World War II.

The collapse of the imperial deterrent occurred gradually for Portuguese Brazil and abruptly for the Spanish Americas. In Brazil, the Portuguese government fleeing Napoleon’s army arrived in ships protected by the British fleet in 1807. Independence occurred when the king reluctantly returned to Lisbon in 1821, leaving his son behind to declare Brazil an independent 'empire.’ In the Spanish case, the imperial deterrent collapsed abruptly when Napoleon suddenly turned on the Spanish government. In 1808, he hustled the king (Carlos IV) and his eldest son (Fernando VII) off to a golden exile in Provence and installed his brother Joseph on the Spanish throne. By the time Fernando recovered his throne in 1813, both Spain and its empire had changed forever. For a brief time, it seemed possible to restore the status quo ante: the Hidalgo revolt in Mexico was crushed in 1810; dissident movements in the Andes were suppressed shortly thereafter; 
and the Venezuelan rebels led by Bolivar were defeated in 1812. But disaster struck with an army revolt against the Crown in 1820. When the king faltered, settler elites in the empire understood they could no longer rely on Spain to protect them. Indeed, the resumption of Spanish liberal reforms threatened their privileges, just at a time when the scramble for political power already threatened to get out of control. Hidalgo had already proclaimed the end of the caste system and the legal equality of all Spanish subjects. Bolivar and San Martin offered freedom to slaves who joined them. Indigenous populations had stopped paying the hated head tax (tributo). Urban workers with no property demanded voting rights. The settler elites might look back wistfully to a quieter time of stability and order, but, with a weakened Spain turning liberal, insurrection and independence were around the Latin American corner.

As in Spanish America, most of the African anti-colonial movements suffered initial defeats, but external shocks associated with World War II strengthened these movements while weakening the imperial powers. The imperialists traded war services for pledges of citizenship and equality. Financially exhausted by the costs of war, and embattled by anti-imperial uprisings in other portions of the globe, they also conceded power (albeit reluctantly) to local politicians. In the French territories, African voters won the right to elect representatives to the Parliament in Paris. In English-speaking Africa, the British appointed local politicians to legislative institutions; later, they filled these posts through elections; and later still they modified the Executive Council - the colonial governor's Cabinet - in the same manner.

The demise of imperial rule in Latin America and Africa differed in at least one major respect. Imperial political retreat in Africa was accompanied by economic 
investment, and this investment was targeted at the traded portion of the economy. ${ }^{4}$ The European powers emerged from World War II with immense debt and capital shortage; only Portugal emerged relatively unscathed by the fighting. In response to economic exigencies, they rendered imperial policy a branch of national economic policy. This meant promoting protectionism for France. Rather than importing cocoa or coffee from Latin America, France promoted their production in its African colonies. And rather than importing textiles, they instead encouraged national industries to expand their capacity by creating new plants in Africa (Boone 1990). For England and Belgium, it meant enhancing the capacity of their African colonies to produce goods for export to the dollar market. The post-war demand for African commodities grew as did colonial trade surpluses, and these surpluses were transferred to the home country where they were used to retire the war debt. ${ }^{5}$

\section{Independence and Post Imperialism}

\section{Post-Colonial Violence}

As the empires collapsed, so too did the imperial defense against external intervention and the imperial deterrent against internal strife. Latin America fell victim to

\footnotetext{
${ }^{4}$ Latin America experienced a more ephemeral investment cycle in the early to mid 1820s, with two marked differences. First, the capital did not come from their former imperial countries, but rather from private banks and citizens in Britain and the Continent. Second, most of it went into bonds issued by the newly independent governments (though there was significant FDI in mining ventures in several countries, notably Mexico). The boom collapsed as governments defaulted on their debts and insecurity made FDI unprofitable.

${ }^{5}$ In the post-war period, Portugal - which had remained neutral in the World War II - also invested in its African territories. In the 1960s, Portugal promoted the settlement of hundreds of thousands of colonists in Angola and Mozambique. As had the French, Portugal sponsored the production by Portuguese firms in the colonies of goods for export to the homeland, namely, fish, sugar, tea, coffee, tea, textiles, and other products.
} 
numerous external interventions (Table 1). Spain made serious efforts to re-conquer its colonies until well in to the 1830s. Britain, France, Spain, and other powers imposed blockades or landed troops to secure economic and military advantages, or to defend their foreign markets. Elite factions in many former colonies supported these interventions. Beginning in the 1820s, the United States competed directly with the British in Mexico, the Caribbean, Central America, and occasionally elsewhere, the two powers backing opposing factions in local civil conflicts. Relative to the industrial core, Latin America was a violent place between 1820 and 1870 where violent deaths averaged 1.16 per thousand, or 3.7 times that of western Europe.

[Table 1 about here]

Foreign incursions also increased in post-independence Africa. While avoiding a hot war on European soil, the Soviet Union and the United States were quite willing to spar on soil in the developing world. The cold war spilled over into the Congo on several occasions, with the USSR, China and Cuba supporting rebel movements in the East and the United States and its allies in NATO backing the central government. In the Horn of Africa, where tensions between Ethiopia and Somalia bred instability and conflict, the United States and the USSR again backed opposing sides. So too in South Africa, where the United States supported the Apartheid regime and its occupation of Namibia, while the Soviets and Cubans backed liberation movements there and in the Portuguese colonies of Mozambique and Angola. The result, especially in Angola, was widespread destruction of property and thousands killed.

The newly independent Latin American countries did not possess internationally or even domestically recognized boundaries. Border wars, especially in Central America, 
were provoked by efforts to reunify now-independent territories. The conflicts were very costly: between 1822 and 1860, military expenditures averaged about $77 \%$ of total budgets in Latin America. Conflicts over borders were less prevalent in Africa. Insofar as they did occur, they tended to center in the Horn, where Somalia sought to unite all Somalis into a single state, or to involve secessionist movements, as in Ethiopia, Nigeria, and Congo. Wars against minority regimes were more common, particularly in Southern Africa, where some were maintained by imperialist powers and others by colonial settlers. Many new African states virtually imploded after independence. Table 2 summarizes evidence relating to violence in Africa between 1950 and 1973. Violent deaths averaged 2.38 per thousand in Africa over that period, or 6.4 times the OECD (see Table 2 for sources).

[Table 2 about here]

\section{Lost Decades and Violence}

In post-colonial Latin America and Africa, high levels of violence, political instability, economic balkanization, and anti-trade policies all sabotaged economic growth and reduced state capacities below the already low levels that had characterized the colonial regimes.

Table 3 summarizes Latin American economic performance between 1820 and 1870, where it is compared with the European 'core' (what we call in Table 3 the OECD) and with post-1950 Africa. Latin American per capita GDP growth rates were 0.07\% per annum, or, adjusting for the dubious quality of the data, about zero. This during a period when per capita GDP was growing at 1\% per annum in the industrializing European core. 
The post-independence decades were clearly ones of dramatic falling behind for Latin America, and the correlation between conflict, violence and instability, on the one hand, and poor growth, on the other, was causal (Ponzio 2005). The African per capita GDP growth rate was 0.89\% per annum between 1950 and 1992, this during an era when the European industrial core grew almost three times as fast. These post-independence decades were ones of dramatic falling behind for Africa, and it appears, once again, that conflict, violence and political instability were the root causes (Easterly and Levine 1997; Collier et al. 2002; Artadi and Sala-i-Matin 2003). In short, economic performance in the half-century after independence was abysmal in both Latin America and Africa in the post-imperial era. Lost decades indeed.

\section{[Table 3 about here]}

Collier and his collaborators (2002) offer insight into the impact of violence on private capital in Africa. Conflict affected both the composition and the quantity of capital. In the face of political instability, uncertainty over property rights and potential violence, individuals tend to hold more mobile forms of capital, liquid rather than fixed investments or land. And when fighting destroys old capital, investment in new capital also declines. The reduction in the demand for capital and the shift from fixed to liquid assets both promote capital flight. One estimate has it that $40 \%$ of private African wealth had been moved offshore by 1980: that "Africa has such a high proportion of its wealth abroad despite being capital-scarce is an indication of how much ... other variables [like violence] matter” (Collier et al. 2002: 22). The authors imply that the threat of violent conflict is among the most important of these variables. 
Using data for 1960-1996 from 43 African countries, Gyimah-Brempong and Corley (2005) find both a direct and a lagged relationship between civil war and economic growth, the channel of influence running through capital formation. The impact was very large relative to average growth rates, something in excess of 4 percentage points. Collier and his colleagues (1999) calculate that the longer term effect - or the 'overhang' as they call it - has amounted to a reduction of 2.1 percentage points over the five years following a civil war. While lower than the Gyimah-Brempong and Corley (2005) estimate, it is sufficient to account for a major portion of the lost decades gap between Africa's GDP per capita growth rate and that of other parts of the world.

Either 1989 or 1991 could be taken as marking the end of the Cold War, and at that time Africa had about a quarter of the world's nations, ${ }^{6}$ about a tenth of the world's population and about a twentieth of the world's economic product. If dated with the fall of the Berlin wall in 1989, then $46 \%$ of the world's civil wars were African at the end of the Cold War. If dated by the fall of the Soviet Union in 1991, the figure is $53 \%{ }^{7}$ In recent years, then, Africa has certainly supplied far more than its share of violent political conflict! It is perhaps for this reason that agencies rate Africa as the riskiest continent for investors (Collier et al. 1999). One can only suppose that the same political instability and violence explains the lack of foreign capital in post-independence Latin America after 1850 when the late $19^{\text {th }}$ century global capital market started its boom (Obstfeld and Taylor 2004).

\footnotetext{
${ }^{6}$ The denominator is the number of members of the United Nations (UN) or the number of nations with a population of one-million or more (POP). The numerator is the number of countries in Sub-Saharan Africa (SSA), or the number of countries in Africa with a population of one million or more (SSA-POP). Accordingly, Africa's percentage of the world's nations is SSA/UN= 25\%; or (SSA-POP) $/(\mathrm{POP})=23 \%$.

7 The figures are calculated from data gathered by the Peace Research Institute in Oslo on conflicts between insurgent groups and governments that generate 1,000 or more battle deaths per annum (Strand et al. 2002).
} 


\section{Lost Decades, Balkanization and Anti-Market Policy}

Both Latin America and Africa also suffered from economic balkanization which stemmed from fiscal, currency and market fragmentation. It might be supposed that balkanization in Latin America (Irigoin 2003; Prados 2006; Grafe and Irigoin 2006) would have had a smaller impact than in Africa since inter-colonial trade in the Americas had been modest or forced by colonial fiat. ${ }^{8}$ However, protectionism driven by warrelated revenue needs diminished the positive impact that could have been expected from the destruction of the Iberian commercial monopolies. In any case, Table 4 gives us some notion as to what was lost by market fragmentation and protection in Latin America: in 1820, the two biggest Spanish American economies had an average market size (GDP) only about one-quarter that of the average European core (OECD) country. The same was true of Brazil. In 1870, the figure for Argentina, Chile and Mexico combined was oneseventh of the average European core country. If scale economies and internal trade mattered as much as economists think, Latin America lost a lot after independence since the combined market size of the former Spanish Americas was at least three-quarters the size of the average European core country, or more.

[Table 4 about here]

Balkanization took place in post-independence Africa as well, and to an even greater degree. By 1960, the French colonies had opted for self-government ${ }^{9}$ and out of their respective federations. While they remained within a currency zone managed by France, each could now impose tariffs, regulate trade, and manage transport services with

\footnotetext{
${ }^{8}$ For example, the inclusion of Upper Peru (Bolivia) within the Viceroyalty of La Plata, created in 1776, forced Bolivian miners to send their silver overland to Buenos Aires to be exported and to import products (mules, sugar) only from Argentina.

9 Technically, they opted for "autonomy within the French community."
} 
an eye to their respective national jurisdictions rather than to international markets. The achievement of independence by Zambia and Malawi marked the break-up of the Federation of the Rhodesias and Nyasaland. The East African High Commission also broke apart, as newly-independent Uganda and Tanzania sought to promote the growth of local industry. Throughout Africa, each newly-independent country issued its own currency. Both English- and French-speaking countries regulated the flow of labor and capital across its boundaries. Most also opted for import substituting industrial policies, seeking to promote the formation of local manufacturing despite the small size of local markets. In addition, governments adopted policies that fragmented transport networks. These hit hardest in southern Africa, where the imposition of economic sanctions on white minority regimes led to the seizure of railway rolling stock and the blockage of road shipments. Whether the comparison is made for 1950 or 1992, the average African economy had a market size only one-tenth that of the average OECD country.

Economic growth in the post-imperial period was further impeded by policy choices in both regions. Not only did violent conflict raise the cost of doing business, but it also raised the demand for public revenues. New governments at war certainly needed revenues that could be collected easily, and there were other motivations to protect in Latin America. ${ }^{10}$ Thus, one reason why Latin America failed to exploit the world trade boom before the belle époque was that it adopted aggressive anti-trade policies.

Similarly, Africa failed to exploit the world trade boom which started sometime around 1950. Table 5 offers some summary statistics confirming that both regions were highly

\footnotetext{
${ }^{10}$ By 1865, and with the exception of the United States, Latin America had the highest tariffs in the world (Coatsworth and Williamson 2004). High post-independence tariffs in Latin America can be explained by war revenue needs, redistribution goals, domestic industrial policy, as well as other forces (Williamson 2006a: chp. 7; Williamson 2007).
} 
protectionist, anti-global, had high tariffs (and export taxes), and relied heavily on customs duties as a source of revenue. The average Latin American tariff rate in 1870 was about $24 \%,{ }^{11}$ which was more than four times that of the European core. In the modern era where non-tariff barriers can be more effective in reducing trade, the tariff rate for Africa between 1971 and 1999 was still almost 15\%, more than 30 times that of the OECD. Both regions scored or would have scored extremely low on the SachsWarner openness index. In the case of Latin America, these negative anti-global factors swamped the positive effects that should have come from the dissolution of the Spanish imperial trade monopoly. ${ }^{12}$

[Table 5 about here]

Most post-independence African governments adopted what could be called 'control regimes,' a phrase which refers to a mix of anti-market policies, the most notable features of which were: the movement to a closed economy; the regulation, sponsorship and promotion of industry; and widespread intervention in markets (Ndulu and O'Connell 2007). Prevailing economic doctrines, political commitments to socialism, and pressures for economic redistribution put a premium on interventionist policies. Indeed, governments adopted such policies in $60 \%$ of the cases by the mid-1970s (Figure 1 ) ${ }^{13}$ Thus, while the coastal economies of independent Africa may have been spared civil war in the post-imperial period (Figure2), like the rest of Africa they were still subjected to central economic control and anti-trade policies. This may help explain their failure to

\footnotetext{
${ }^{11}$ An average tariff rate of $24 \%$ may seem modest, but it was consistent with much higher tariffs on importcompeting goods, like manufactures.

${ }^{12}$ Brazil is an exception to the rule. Virtual free trade had been declared by the Portuguese king, João IV, on his arrival in the colony in 1808, but the impact was minimal. Regional, separatist, and slave revolts wracked the country after independence, generating revenue needs and tariffs, although a commercial treaty with Britain kept tariff rates low initially.

${ }^{13}$ The figure exploits 46 countries, and averages over five year periods.
} 
emulate the growth performance of coastal economies in other parts of the developing world in the late $20^{\text {th }}$ century, especially those of Asia.

[Figures 1 and 2 about here]

\section{The World Economic Environment}

What about exports per capita, another measure of openness? Table 6 reports impressive growth rates 1850-1912, after the lost decades, averaging a little more than 2 percent per annum over the 62 years. The half century before 1850 is quite a different story: except for Chile, the growth rates of exports per capita are below 1 percent per annum, and in three cases they are below 0.4 percent per annum. The source of low and stable exports was certainly not faltering world demand since during its lost decades Latin America shared in the spectacular secular terms of trade boom which favored all commodity exporting periphery regions (Williamson 2006a: chp. 6). True, Figure 3 suggests that Latin America had a less dramatic boom than did the rest of the periphery, but over the four decades between 1820 and 1860 the ratio of export to import prices in Latin America rose by more than 50\%.

What about post-independence Africa? Figure 4 presents a terms of trade series for sub-Saharan Africa from 1960 to 2003. While the mid-late 1980s were certainly bad years for its commodity prices, Africa had twenty or even forty years (if we reach back to 1940: Deaton 1999) of strong markets for its exports. Thus, the African and Latin American lost decades cannot simply be laid at the feet of poor world markets.

[Figures 3 and 4, and Table 6, about here] 


\section{Violence and the Drift to Liberalism}

Post-independence violence and economic decline in both Africa and Latin America reduced state capacities and thus undermined economic strategies that required strong, centralized national governments - conservatism in most of Latin America, and “socialist” and regulatory states in Africa. Violence undermined many key institutions of colonial rule in Latin America: caste systems, slavery, state monopolies, internal customs, ${ }^{14}$ trade regulations, taxes and fees that burdened urban consumption, state collection and enforcement of the tithe, and archaic property rights in land (like entail and mortmain). Conservative governments attempted to revive elements of the caste system in Bolivia and Peru, but enforcement depended on indigenous collaboration, which soon evaporated. Slave systems were undermined in western Hispaniola (Dominican Republic) and in those mainland colonies where independence leaders offered freedom to slaves who joined them (Bolivar in Venezuela and Columbia, San Martin in Argentina and Chile). Secularizing governments stopped enforcing the tithe. Entail (mayorazgo) was abolished. Church property was disentailed, and when the church resisted (as in Mexico), its properties were expropriated and sold. The hitherto inalienable lands assigned to indigenous villages and town councils (cabildos, ayuntamientos) were sold and efforts were undertaken to privatize public lands through auctions, grants, and colonization schemes. Reforms of the property rights system culminated in new civil and commercial codes after mid century. Fiscal necessity as much as ideology drove much of this activity,

\footnotetext{
${ }^{14}$ This entailed the elimination of customs houses along roads and at city gates. Furthermore, restrictive regulations were abandoned, such as the rules mandating seizure of imported goods that deviated from specified routes into the interior and required document called guias to be signed at each destination and returned to the port of entry. All of these reforms were trade-creating, of course.
} 
often accompanied by new tariff codes, fiscal reform, and the reorganization of judicial systems.

The net effect of these institutional changes was to liberate economic activity from a burdensome colonial legacy. In that sense, Latin America's civil wars and international conflicts of the post independence decades had a modernizing impact. They undermined and made unenforceable both the state-sanctioned private privileges of the region's European elites and the myriad internal taxes, regulations, monopolies of the colonial regime. Latin America began drifting toward liberalism long before it became an ideology and a slogan.

Economic decline also undermined state-centered economic strategies in Africa and set in motion the liberalization of economic policies. Governments that had overvalued their currencies, undermined export incentives and created incentives for smuggling. Because taxes on trade represented so large a portion of public revenues, public revenues declined. In addition, governments that had regulated industries and imposed price controls, created incentives for economic activity to shift to the informal economy, where it remained untaxed.

Interventionist policies in Africa often added to fiscal crisis thus contributing to the collapse of political order. Further, as governments had retained power by targeting economic benefits to core constituencies, the decline in public revenues led to a rise in political instability. When governments could not pay their military forces - or paid them in worthless currencies, soldiers began to pay themselves in kind by engaging in extortion and looting, giving rise to high levels of economic insecurity. 
A rising African public debt was held by international financial institutions, particularly the World Bank, which by the late $20^{\text {th }}$ century had assumed a major portion of the costs of government in Africa. The Bank increasingly pressured African governments to abandon policies that sought to override market forces and to adopt policies that harnessed market incentives (World Bank 1989). Attempts to stabilize the political and economic fortunes of the state in Africa thus led to liberal policy reform: abandonment of public deficits, price controls, and government monopolies (World Bank 1994). Figure 5 depicts the movement toward what has been labeled 'syndrome free' policies (Collier and O'Connell 2007).

[Figure 5 about here]

\section{Why Were the Lost Decades So Long?}

Neither the pre-modern Iberian powers in Latin America nor the modern imperialists in Africa sought to create the social base for economic dynamism in their colonies. Nor did they succeed in doing so in spite of themselves. Latin America's liberal drift took decades for two reasons: resistance by powerful settler elites and the relative weakness of the liberal movements that sought to dislodge them. In the most populous Latin American colonies, typified by Mexico and Peru, pre-independence economic elites resisted change because their class and ethnic interests linked them to the colonial regime. Colonial constraints on economic activity had impeded the development of an entrepreneurial or business class strong enough to end the dominance of the colonial elites and the civil strife that accompanied independence impoverished many whose occupations and interests inclined them toward liberalism. Argentina was exceptional in 
that the absence of either an indigenous underclass or plantation slavery narrowed the post independence conflicts to squabbles over the spatial distribution of political power, with most liberals supporting a 'unitary' regime dominated by the port city of Buenos Aires. In other large countries, liberals were inevitably federalist, because they sought to accelerate the drift toward freer markets by making national governments even weaker. Political stalemate and economic stagnation slowed and at times partially reversed the region's inexorable, if sometimes glacial draft toward liberalism,

In Africa, the delay in economic reform reflected the power of a perverse equilibrium where key actors realized the costs of inappropriate policy choices but could not unilaterally abandon their commitment to them. Policies toward agriculture illustrate the point. Urban labor, industry, and the governments themselves championed 'low price' policies for basic foodstuffs. Through retail price controls, monopsony purchasing, and the opening up of domestic markets to foreign imports (which could be purchased with over-valued currencies), governments sought to provide urban consumers with cheap food (Bates 1981). These policies raised real incomes for city workers, but also lowered the own-wage of urban labor and thus defended industrial profits. But these pro-urban policies undercut the profitability of agriculture (the largest sector of most African economies), and led - perversely but inevitably -- to shortages and higher prices, and reduced economic growth rates while undermining the legitimacy of governments.

While the policies thus imposed significant costs on Africa's states, they nonetheless endured. No labor leader could afford to demand their reversal. And no political leader could champion policies that would, initially at least, raise the cost of 
living for urban consumers. As a result, the policies remained in place, even while undermining the economic wellbeing of the states that retained them.

\section{Reform and Recovery}

Nearly everything changed in Latin America after 1870. First, there came political (and often military) victory of Liberal political forces that imposed civic equality without regard to ethnicity, abolished slavery, separated church and state, put an end to archaic property rights in land, privatized public assets (especially land), and finally abolished internal customs and public monopolies. Second, long term stability was secured in most cases by means of historic compromises that reunited elite economic interests. Once conservatives accepted the new rules of the game, militarism and popular mobilization were replaced by governing arrangements that provided major domestic and foreign business groups secure access to influence. Third, the new political economy came to be embodied in modern civil and commercial codes, judicial reform and reorganization, new banking and insurance laws, renegotiation of domestic and external debts, tariff protection for industries in the larger economies, increasing public investment in physical infrastructure and security. Fourth, stability facilitated economic growth, which helped to cement the new political economy (Ponzio 2005): the income per capita growth rate was 1.8\% per annum for Latin America between 1870 and 1913 (Maddison 2003: 142). Economic growth was sustained by new investment, particularly foreign direct investment, which came first in response to government guarantees and subsidies 
(railroads, public works, banking), and then to exploit new opportunities in export production and industry (Obstfeld and Taylor 2004).

These changes could not have been achieved in most countries without the previous conflict and bloodshed. Civil warfare destroyed many of the colonial institutions that Liberals sought to abolish long before the fighting stopped. This destructive phase of institutional modernization facilitated the transition to a second more constructive phase in which governments discovered -- often through trial and error over two or three decades -- the institutional arrangements and policies most likely to encourage investment and growth. The new regimes succeeded in eliminating (or at least diminishing) the political participation of popular classes especially in the countryside. They centralized power in provincial and national capitals, away from villages and small towns. They also installed, or enforced more rigorously, property and literacy limits on the franchise. Success in excluding most citizens from political influence and participation aided stability and economic growth, but disfavored a more egalitarian society and maximized short run returns on social overhead capital, foreign investment, foreign technology, and foreign skills. Still, most stable Latin American regimes of the late nineteenth century lacked the capacity or the incentives to create institutions that could credibly guarantee the property and civic rights of most citizens or give priority to investments in human capital. Thus, institutions favoring inclusive development did not develop.

Sustained economic growth in the Latin American belle époque yielded an even greater concentration of assets and income. Economic modernization provoked 
widespread increases in the concentration of land ownership, ${ }^{15}$ wages rose more slowly than did per capita GDP (Williamson 1999), and inequality rose overall (Prados 2005). Those Latin American economies which achieved long term GDP per capita growth rates comparable to the United States (roughly 1.5\% per year over the twentieth century), achieved it at the cost of persistent inequality and chronic social and political tension. In recent years, Africa has experienced a decline in political conflict. While conflict continues on the Horn of Africa, the liberation wars in Southern Africa have come to an end; so too have the civil wars that followed the achievement of independence in Mozambique and Angola. While Chad, Cote d'Ivoire, Ethiopia, Somalia, Sudan and Zimbabwe are still torn by civil war, fourteen others have dropped from that list (Angola, Benin, Djibouti, Kenya, Liberia, Mali, Mozambique, Namibia, Nigeria, Rwanda, Senegal, Sierra Leone, Uganda, and Congo). In many - especially Congo, Burundi, and Nigeria - peace remains fragile, but at least military conflict has stopped.

A corollary of institutional reform was policy reform, with the abandonment of control regimes in favor of ones producing fewer price distortions, a greater reliance on market incentives, and less government regulation (see Figure 5: Ndulu et al. 2007). Unlike Latin America, where newly stable regimes worked to exclude majorities by restricting the franchise, Figure 6 shows that in Africa no-party (largely military) and single-party systems gave way to competitive party systems during the period of democratic reforms in the 1990s. That institutional reform and policy reform should go together in Africa should not be surprising. Small holder farms face high costs of organization, and so were ineffective lobbyists; but, being numerous, they constitute a large bloc of voters. And with the reintroduction of competitive party politics, rulers then

${ }^{15}$ For the Mexican case, see Coatsworth (1974). 
faced incentives to abandon the policies that had so long imposed heavy burdens on agriculture.

Contemporary Africa has also experienced a rise in the demand for its exports. Fueled by the growth of Asian economies, and the economy of China in particular, Africa now benefits from a growing demand for primary products: timber, oil, and metals, in particular. ${ }^{16}$ The result has been the achievement of the first spell of positive rates of economic growth since the first decade of independence, some 40 years previously (Table 7).

[Figure 6 and Table 7 about here]

\section{Historical Lessons for Africa's Future}

The comparison we have offered suggests cautious optimism for Africa's future. One the one hand, Latin America finally emerged from the post-independence period into a second half-century of impressive growth and political stability, and there are signs that Africa may emulate Latin American experience. On the other hand, the social costs of the policies that led to this Latin American outcome were high, generating benefits to the few, economic inequality, and political exclusion. If history repeats, Africa too can grow, but the danger is that the achievement of economic growth and political stability may also come at high social cost.

\footnotetext{
${ }^{16}$ It also benefits from a demand for simple labor-intensive manufactures. Sub-Saharan Africa is shifting out of mineral and agricultural exports and in to manufactures, although it only became apparent in the early 1990s. The share of manufactures in total exports in this region was only 12 or 13 percent in 1991, while it was almost 50 percent in 1998 (Martin 2003; Williamson 2006b: Figure 6).
} 
The 1990s were marked by the rise of democracy and the overthrow of authoritarian regimes in Africa. Instead of single party politics or military rule, multiparty politics prevailed in nearly $70 \%$ of Africa by 1995 . In addition, governments increasingly adopted more liberal economic policies. The fall of communism, external pressures for policy reform, and the simple fact that governments that wished to remain in power had to compete for votes and so could no longer impose the kinds of policies that they once had favored. An economic benefit accompanied the end of political conflict. Much of Africa began to adopt more market-oriented policies to exploit those benefits. And a little help from expanding world markets reinforced improved economic performance: the rising demand for primary products from Asia's growing economies has helped spark a resumption of growth in $21^{\text {st }}$ century Africa just as an accelerating world industrial revolution helped create the belle époque for late $19^{\text {th }}$ century Latin America.

But will Africa pay the same price for modern economic growth as did Latin America? Will the growth of exports, the abandonment of monopolies, and the promotion of markets be accompanied by the rise of inequality and the consolidation of power by an oligarchic elite? There are certainly signs of such a trend: the privatization of public assets in Africa has already led to their accumulation by the political elite and a strengthened link between wealth and power. In two fundamental ways, however, Africa's evolution is departing from Latin America history. First, there are no restrictions on the franchise in Africa's emerging democracies, while there certainly were in most of Latin America until after 1950. Second, recall that Africa's population is composed of a far larger share of indigenous people and a far smaller share of European settlers and their descendants than was true of Latin America 150 years ago. As a result of the vastly 
greater political weight of the indigenous population, the reform of private property rights to land, which could lead to concentration and inequality, remains off the political agenda in most African states, whereas it was central to the political agenda of the liberal regimes in $19^{\text {th }}$ century Latin America. Thus, perhaps Africa will not have to pay the same social inequality price for modern economic growth that Latin America did following its lost decades. 


\section{References}

D. Abernethy (2000), The Dynamics of Global Dominance: European Overseas Empires, 1415-1980 (New Haven, Conn.: Yale University Press).

E. V. Artadi and X. Sala-i-Matin (2003), “The Economic Tragedy of the XXth Century: Growth in Africa,” NBER Working Paper 9865, National Bureau of Economic Research, Cambridge, MA. (July).

A. S. Banks (1976), Cross-National Time Series 1815-1973 (online), Inter-University Consortium for Political and Social Research, Ann Arbor, Michigan.

R. H. Bates (1981), Markets and States in Tropical Africa (Berkeley and Los Angeles: University of California Press).

R. H. Bates (2007a), "Chapter 4: Domestic interests and control regimes." In B. Ndulu, P. Collier, R. Bates, and S. O'Connell (eds.), The Political Economy of Economic Growth in Africa, 1960-2000 (Cambridge: Cambridge University Press, forthcoming).

R. H. Bates (2007b), "Chapter 7: Political conflict and state failure." In B. Ndulu, P. Collier, R. Bates, and S. O'Connell (eds.), The Political Economy of Economic Growth in Africa, 1960-2000 (Cambridge: Cambridge University Press, forthcoming).

R. H. Bates (2007c), "Chapter 10: Political reform." In B. Ndulu, P. Collier, R. Bates, and S. O'Connell (eds.), The Political Economy of Economic Growth in Africa, 19602000 (Cambridge: Cambridge University Press, forthcoming). 
C. Boone (1990), Merchant Capital and the Roots of State Power (New York: Cambridge University Press).

J. H. Coatsworth (1974), "Railroads, Landholding and Agrarian Protest in the Early Porfiriato," Hispanic American Historical Review 54 (February): 48-71.

J. H. Coatsworth (1988), "Patterns of Rural Rebellion in Latin America: Mexico in Comparative Perspective.” In F. Katz (ed.), Riot, Rebellion, and Revolution (Princeton: Princeton University Press).

J. H. Coatsworth (1998), “Economic and Institutional Trajectories in Nineteenth-Century Latin America.” In J. H. Coatsworth and A. M. Taylor (eds.), Latin America and the World Economy Since 1800 (Cambridge: Harvard University Press).

J. H. Coatsworth and J. G. Williamson (2004), "The Roots of Latin American Protectionism: Looking Before the Great Depression.” In A. Estevadeordal, D. Rodrik, A. Taylor and A. Velasco (eds.), FTAA and Beyond: Prospects for Integration in the Americas (Cambridge, Mass.: Harvard University Press).

P. Collier, A. Hoeffler, and C. Patillo (1999), "Flight capital as a portfolio choice." Unpublished, International Monetary Fund (Washington D.C.).

P. Collier, A. Hoeffler, and C. Pattillo (2002), "Africa's exodus: Capital flight and the brain drain as portfolio decisions." Unpublished, World Bank (Washington D.C.).

P. Collier and S. O'Connell (2007), "Chapter 2: Opportunities, choices and syndromes." In B. Ndulu, P. Collier, R. H. Bates and S. O'Connell (eds.), The Political Economy of Economic Growth in Africa, 1960-2000 (Cambridge: Cambridge University Press, forthcoming). 
A. Deaton (1999), “Commodity Prices and Growth in Africa,” Journal of Economic Perspectives 13 (Summer): 23-40.

W. Easterly and R. Levine (1997), "Africa's growth tragedy: Policies and ethnic divisions," Quarterly Journal of Economics 112: 1203-50.

R. Grafe and M A. Irigoin (2006), "The Spanish Empire and Its Legacy: Fiscal Redistribution and Political Conflict in Colonial and Post-Colonial Spanish America,” GEHN Working Paper 23/06, London School of Economic (May).

K. Gyimah-Brempong and M. E. Corley (2005), "Civil Wars and Economic Growth in South Africa," Journal of African Economies 14: 270-311

A. G. Hopkins (1973), An Economic History of West Africa (New York: Columbia University Press).

M. A. Irigoin (2003), “Macroeconomic Aspects of Spanish American Independence: The Effects of Fiscal and Currency Fragmentation, 1800s-1860s,” Working Paper 0345, Universidad Carlos III de Madrid (September).

H. Kjekshus (1977), Ecology Control and Economic Development in East African History: The Case of Tanganyika 1850-1950 (London: Heineman). M. Livi-Bacci (2006), “The Depopulation of Hispanic America after the Conquest,” Population and Development Review 32 (June): 199-232.

A. Maddison (2003), The World Economy: Historical Statistics (Paris: OECD). W. Martin (2003), “Developing Countries’ Changing Participation in World Trade,” World Bank Research Observer 18(20): 187-203. 
B. Ndulu (2007), "Global Influences on Africa's Development." In B. Ndulu, P. Collier, R. H. Bates S. O'Connell (eds.), The Political Economy of Economic Growth in Africa, 1960-2000 (Cambridge: University of Cambridge Press, forthcoming).

B. Ndulu, P. Collier, R. H. Bates S. O'Connell (eds.) (2007), The Political Economy of Economic Growth in Africa, 1960-2000 (Cambridge: University of Cambridge Press, forthcoming).

B. Ndulu and S. O'Connell (eds.) (2007), Development Deferred: Explaining Africa's Economic Growth, 1960-2000 (Cambridge: Cambridge University Press).

M. Obstfeld and A. M. Taylor (2004), Global Capital Markets: Integration, Crisis, and Growth (Cambridge: Cambridge University Press).

T. Pakenham (1991), The Scramble for Africa, 1876-1912 (London: Abacus).

R. Palmer and N. Parsons (eds.) (1977), The Roots of Rural Poverty in Central and Southern Africa (London: Heinemann).

C. A. Ponzio (2005), "Looking at the Dark Side of Things: Political Instability and Economic Growth in Post-Independence Mexico,” unpublished manuscript.

L. Prados de la Escosura (2005), “Growth, Inequality, and Poverty in the Long Run: Latin America in the OECD Mirror.” Paper presented to the conference on The New Comparative Economic History: Essays in Honor of Jeffrey G. Williamson, Harvard University, Cambridge, Mass., November 4-6.

L. Prados de la Escosura (2006), “The Economic Consequences of Independence in Latin America.” In V. Bulmer-Thomas, J. Coatsworth and R. Cortes Conde (eds.), Cambridge Economic History of Latin America Volume I (Cambridge: Cambridge University Press). 
J. D. Sachs, A. Warner, A. Aslund, and S. Fischer (1995), "Economic Reform and the Process of Global Integration,” Brookings Paper on Economic Activity (1): 1-118.

R. L. Scheina (2003), Latin America's Wars: Volume 1 (Washington, DC: Brassey’s).

J. D. Singer and M. Small (1972), The Wages of War 1816-1965 (New York: John Wiley).

H. Strand, L. Wilhelmsen, and N. Gleditsch (2002), Armed Conflict Data Codebook (Oslo: Peace Research Institute).

J. G. Williamson (1999), "Real Wages, Inequality, and Globalization in Latin America Before 1940,” Revista de Historia Economica 17 (special number): 101-42.

J. G. Williamson (2006a), Globalization and the Poor Periphery before 1950 (Cambridge, Mass.: MIT Press).

J. G. Williamson (2006b), “Globalization, De-Industrialization and Underdevelopment in the Third World Before the Modern Era," Journal of Iberian and Latin American History_(Revista de Historia Económica) 24 (Primavera): 9-36.

J. G. Williamson (2007), “Explaining World Tariffs 1870-1938: Stolper-Samuelson, Strategic Tariffs and State Revenues.” In R. Findlay, R. Henriksson, H. Lindgren and M. Lundahl (eds.), Eli F. Heckscher, 1879-1952: A Celebratory Symposium (Cambridge, Mass.: MIT Press, forthcoming).

A. Young (2005), "The Gift of the Dying: The Tragedy of AIDs and the Welfare of Future African Generations,” Quarterly Journal of Economics 120 (May): 42366.

World Bank (1989), Sub-Saharan Africa: From Crisis to Sustainable Growth (Washington D. C.: The World Bank). 
World Bank (1994), Adjustment in Africa: Reform, Results, and the Road Ahead

(Washington D. C.: The World Bank).

World Bank (2006), World Development Indicators 2006 (Washington D.C.: The World Bank). 
Table 1 Violence Indicators for Latin America 1800-1879

Conflict Rate by Country 1810-1870

\begin{tabular}{lccc|ccc}
\hline Country & \multicolumn{3}{c|}{ International Conflicts } & \multicolumn{4}{c}{ Civil Conflicts } \\
& Started & Ended & In Progress & Started & Ended & In Progress \\
\hline Argentina & 4 & 4 & 0 & 6 & 5 & 1 \\
Bolivia & 3 & 3 & 0 & 0 & 0 & 0 \\
Brazil & 3 & 3 & 0 & 3 & 3 & 0 \\
Chile & 3 & 3 & 0 & 3 & 3 & 0 \\
Colombia & 2 & 2 & 0 & 4 & 4 & 0 \\
Cuba & 1 & 0 & 1 & & & 0 \\
Ecuador & 2 & 2 & 0 & 2 & 2 & 0 \\
Mexico & 5 & 5 & 0 & 3 & 3 & 0 \\
Paraguay & 2 & 1 & 1 & 0 & 0 & 1 \\
Peru & 4 & 4 & 0 & 3 & 3 & \\
Uruguay & 4 & 4 & 0 & 2 & 1 & \\
Venezuela & 1 & 1 & 0 & & &
\end{tabular}

\section{Conflict Rate by}

Decade

\begin{tabular}{|c|c|c|c|c|c|c|}
\hline \multirow[t]{2}{*}{ Decade } & \multicolumn{3}{|c|}{ \# Conflicts (ongoing) } & \multicolumn{3}{|c|}{ Deaths } \\
\hline & Int'I & Civil & Total & Int'I & Civil & Total \\
\hline 1800-1809 & 0 & 0 & 0 & 0 & 0 & 0 \\
\hline $1810-1819$ & 4 & 0 & 4 & 474,360 & 0 & 474,360 \\
\hline $1820-1829$ & 7 & 4 & 11 & 307,439 & 0 & 307,439 \\
\hline 1830-1839 & 5 & 7 & 12 & 2,565 & 6,000 & 8,565 \\
\hline $1840-1849$ & 3 & 8 & 11 & 18,000 & 129,680 & 147,680 \\
\hline $1850-1859$ & 2 & 13 & 15 & 1,300 & 219,388 & 220,688 \\
\hline 1860-1869 & 5 & 10 & 15 & 332,000 & 25,141 & 357,141 \\
\hline $1870-1879$ & 4 & 6 & 10 & 14,000 & 4,500 & 18,500 \\
\hline
\end{tabular}

Note: $0=$ missing or insufficient data. Source: Singer and Small 1972: Chp. 4; Scheina 2003: 93-375; Coatsworth 1988: 36-7. 


\section{Table 2 Violence Indicators for 8 African Countries 1950-1973}

$\begin{array}{lr}\text { Assassinations } & 14 \\ \text { General Strikes } & 6 \\ \text { Guerrila Warfare } & 38 \\ \text { Major Government Crises } & 23 \\ \text { Purges } & 37 \\ \text { Riots } & 102 \\ \text { Revolutions } & 25 \\ \text { Anti-government Demonstrations } & 39\end{array}$

Note: The eight countries are: Cote d'Ivorie, Ethiopia, Ghana, Kenya, Nigeria, South Africa, Tanzania and Zaire. Source: Banks 1976.

Table 3 Summary Statistics of GDP Per Capita Growth 1820-70 and 1820 Levels

$\begin{array}{cccc}\text { Latin America } & \text { Latin America } & \text { Africa } & \text { Africa } \\ \text { 1820-1870 } & \text { As Ratio to OECD } & 1950-1992 & \text { As Ratio to OECD }\end{array}$

GDP per capita level

(in 1990 US dollars)

751

0.44

1099

0.1

GDP per capita growth rate

$0.07 \%$

0.07

$0.89 \%$

0.31

Source: Maddison 2003; Coatsworth 1998.

Notes: All regional averages are weighted by population. Latin America = Argentina, Brazil, Chile, Colombia, Mexico, Peru and Venezuela. Pre-1870 OECD = Austria, Belgium, Denmark, Finland, France, Germany, Italy, Netherlands, Norway, Sweden, Switzwerland, and United Kingdom. Post-1950 Africa = Cote d'Ivoire, Ethiopia, Ghana, Kenya, Nigeria, South Africa, Tanzania, and Zaire. 
Table 4 Market Size During Lost Decades

As Percent of

OECD Average

Latin America 1820

Argentina

5.17

Brazil

25.56

Mexico

42.38

Average

19.32

Latin America 1870

Argentina

9.29

Brazil

28.61

Chile

9.11

Mexico

25.83

Average

18.21

Africa 1950

Cote d'Ivoire

2.90

Ethiopia

5.55

Ghana

5.70

Kenya

4.35

Nigeria

21.61

South Africa

34.11

Tanzania

3.89

Zaire

6.91

Average

10.63

\section{Africa 1992}

Cote d'Ivoire

3.15

Ethiopia

3.57

Ghana

3.46

Kenya

5.85

Nigeria

22.86

South Africa

28.20

Tanzania

3.41

Zaire

2.90

Average

9.17

Source: Market size calculated as GDP. See Table 3. 
Table 5 Summary Statistics on Tariffs and Openness

\section{Average Tariff \\ Rate 1870}

(\%)

\section{Average Tariff \\ Rate 1971-99}

(\%)

\section{Sachs-Warner Open \\ Indicators}

1963 1992
(1) Latin American

(2) Western

Europe

Ratio (1)/(2)

(3) Africa

(4) European OECD

Ratio (3)/(4)

Ratio (4)/(3)
24.1

5.7

4.23

Sources: Tariffrates 1971-99 from World Development Indicators online. SachsWarner Open indicators from Sachs et al. (1995). Latin American 1870 tariff rates from data underlying Coatsworth and Williamson (2004).

Notes: Latin America in 1870 includes Argentina, Brazil, Chile, Colombia, Mexico and Peru. Africa in 1971-99 includes Cote d'Ivoire, Ethiopia, Ghana, Kenya, Nigeria,

South Africa, Tanzania and Zaire. All regional averages are population weighted.

Table 6 Latin American Exports per capita, in current US dollars 1800-1912

\begin{tabular}{lrrrrr} 
& & & \multicolumn{4}{c}{ Growth Rate per annum (\%) } \\
Country/ Year & $\mathbf{1 8 0 0}$ & $\mathbf{1 8 5 0}$ & $\mathbf{1 9 1 2}$ & $\mathbf{1 8 0 0 - 1 8 5 0}$ & $\mathbf{1 8 5 0 - 1 9 1 2}$ \\
Argentina & & & & & \\
Brazil & 10.03 & 10.3 & 62.1 & 0.05 & 2.89 \\
Chile & 4.78 & 5 & 14.2 & 0.09 & 1.69 \\
Cuba & 1.63 & 7.8 & 44.7 & 3.18 & 2.86 \\
Mexico & 18.35 & 22.2 & 64.7 & 0.38 & 1.74 \\
Peru & 2.11 & 3.2 & 10.7 & 0.84 & 1.97 \\
& 2.31 & 3.7 & 9.4 & 0.95 & 1.52
\end{tabular}

Sources: For 1850, Coatsworth (1998: 31). For 1800 and 1812, BulmerThomas (2003: 37). 


\section{Table 7 GDP Per Capita Growth Rates}

2000-2005 (\% per annum)

$\begin{array}{lc}\text { Region } & \text { Growth rate } \\ \text { Europe \& Central Asia } & 5.41 \\ \text { European Monetary Union } & 1.34 \\ \text { East Asia \& Pacific } & 7.17 \\ \text { Latin America \& Caribbean } & 1.21 \\ \text { Middle East \& North Africa } & 2.01 \\ \text { South Asia } & 4.24 \\ \text { Sub-Saharan Africa } & 1.76 \\ \text { Source: World Bank (2006). } & \end{array}$


Figure 1 African Policy Regimes by Period

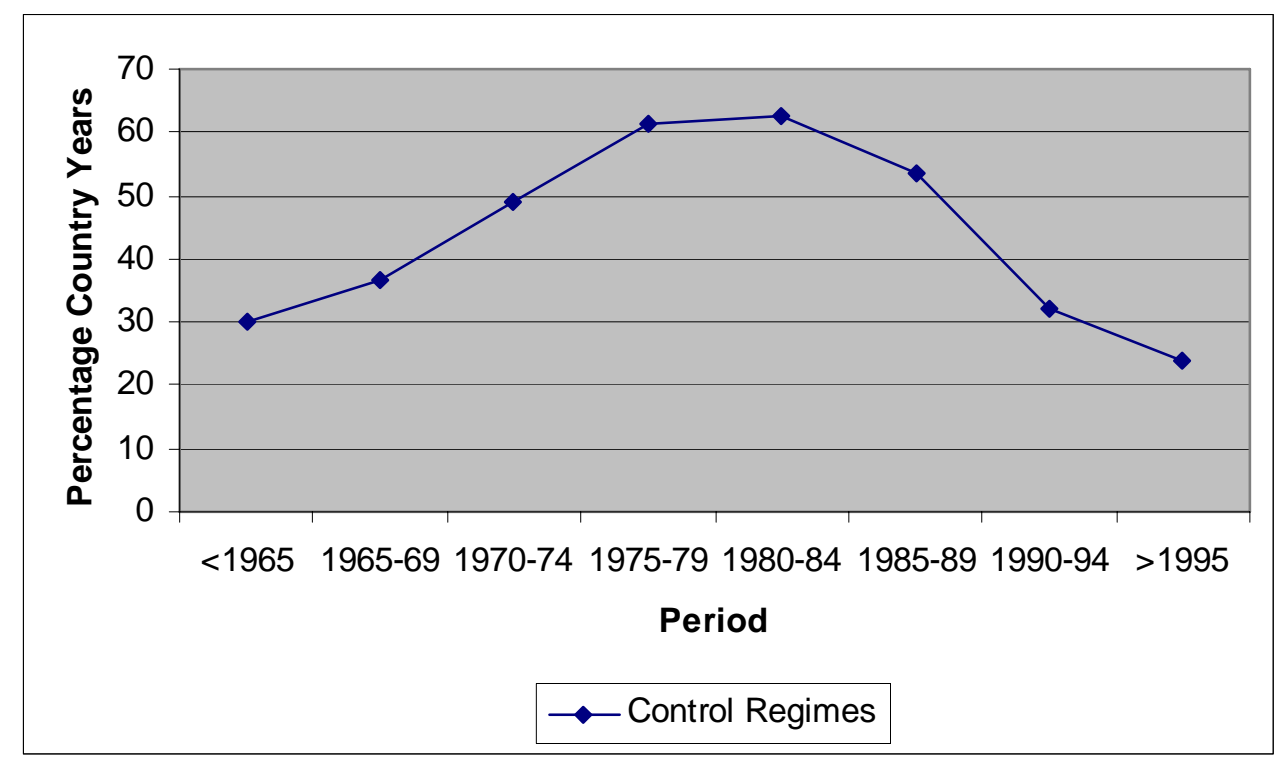

Source: Bates (2007a).

Figure 2 Civil Wars by African Region 1970-1995

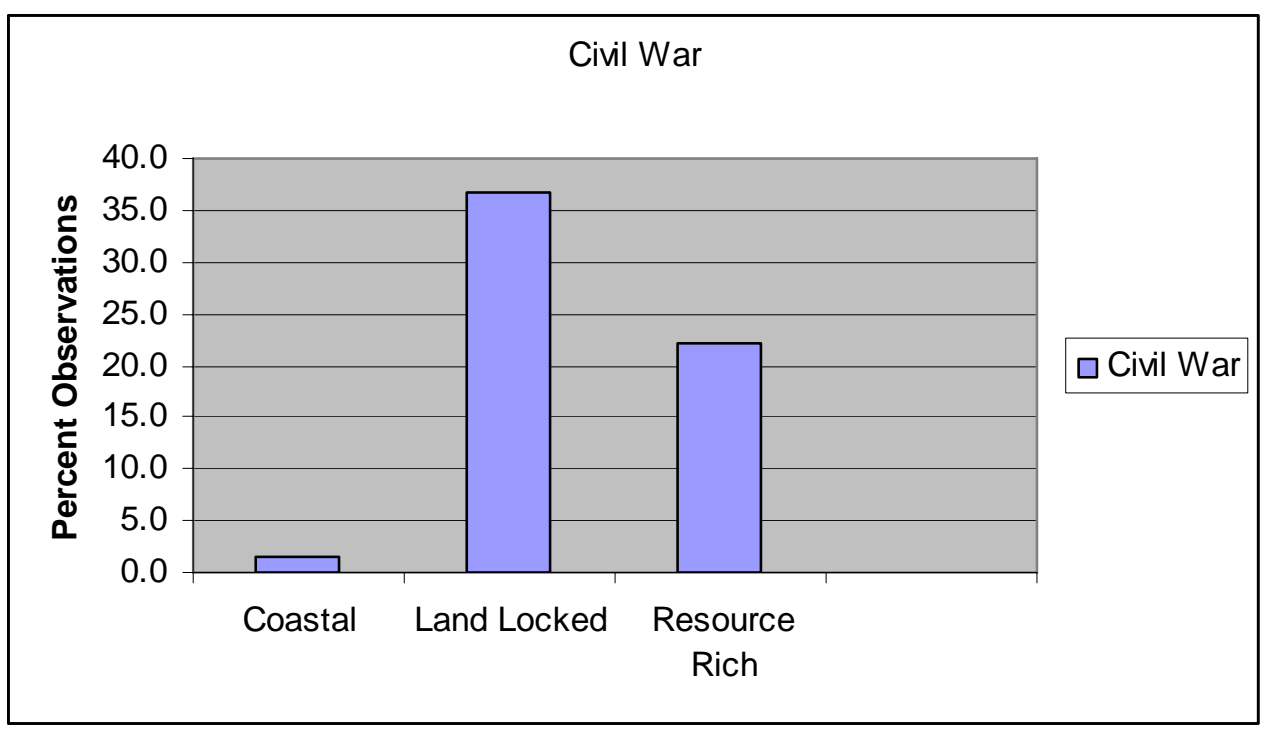

Source: Bates (2007b). 


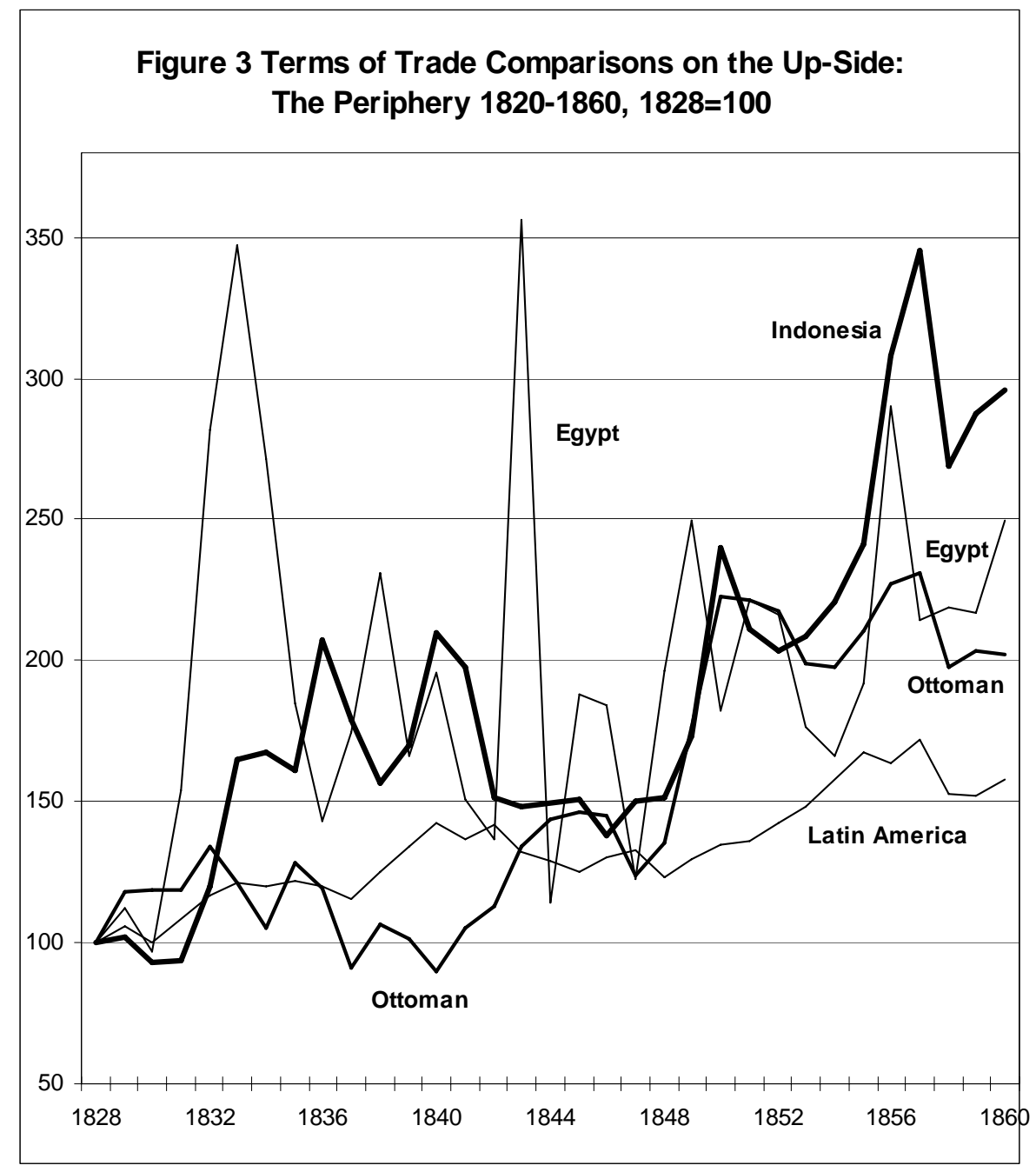

Source: Williamson (2006b). 


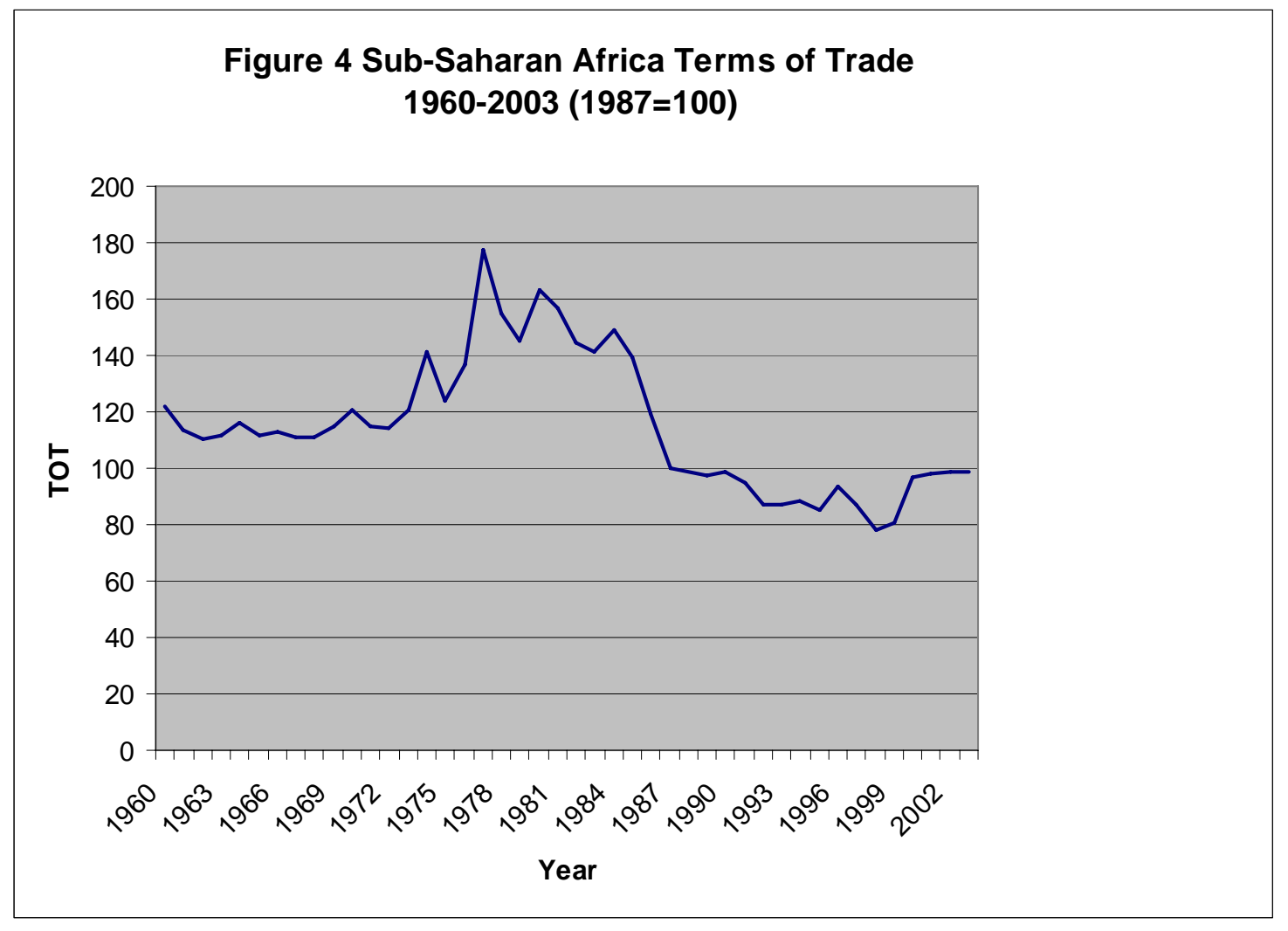

Source: Private correspondence with Steven O’Connell.

\section{Figure 5 African Policy Regimes Over Time}

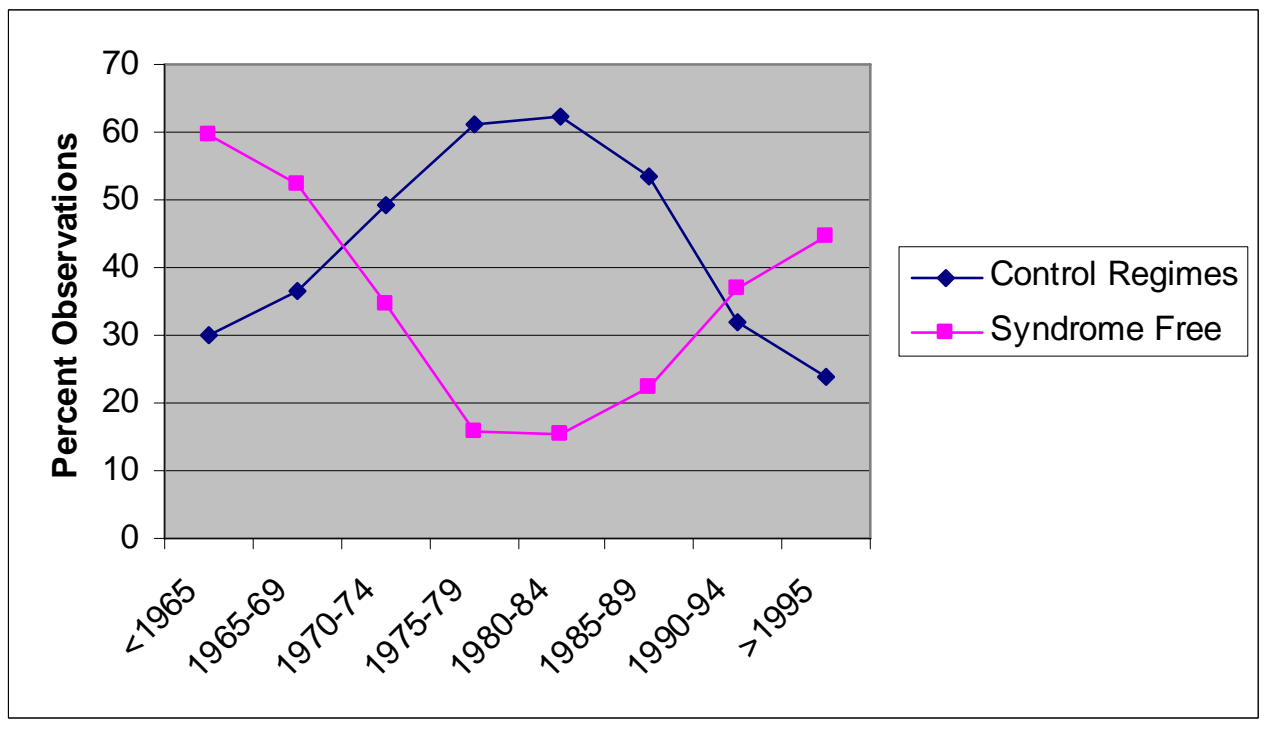

Source: Bates (2007a). 
Figure 6 Political Liberalization in Africa 1970-1995

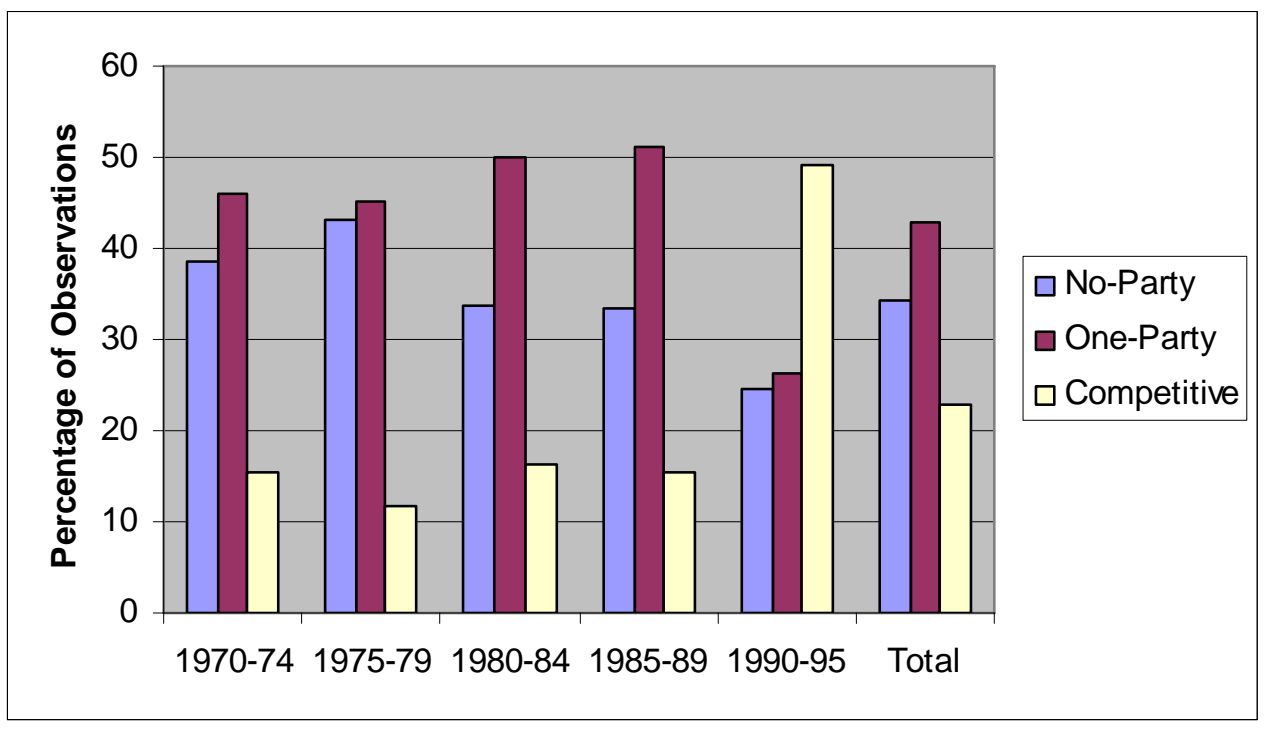

Source: Bates (2007c). 